$\begin{array}{ll}\text { Chirurgia (2020) } & 115: 505-510 \\ \text { No. } 4, & \text { July - August } \\ \text { Copyright@ Celsius } & \text { http://dx.doi.org/10.21614/chirurgia.115.4.505 }\end{array}$

\title{
Left Spermatic Vein Thrombosis - An Uncommon Diagnosis: A Case Report
}

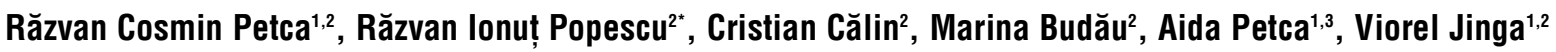 \\ 1"Carol Davila" University of Medicine and Pharmacy, Bucharest, Romania \\ 'Department of Urology, "Prof. Dr. Th. Burghele" Clinical Hospital, Bucharest, Romania \\ ${ }^{3}$ Department of Obstetrics and Gynecology, Elias University Emergency Hospital, Bucharest, Romania
}

*Corresponding author

Răzvan lonuț Popescu, MD

Department of Urology

"Prof. Dr. Th. Burghele" Clinical Hospital

20 Panduri Street, District 5, 050653

Bucharest, Romania

E-mail: dr.razvanp@gmail.com
Received: 16.03 .2020

Accepted: 09.05.2020

\section{Rezumat \\ Tromboză de venă spermatică stângă - un diagnostic neobișnuit: prezentare de caz}

Introducere:Tromboza de venă spermatică este o patologie rară, cu puține semne clinice caracteristice, diagnosticul diferențial şi tratamentul ridicând numeroase controverse.

Prezentarea cazului: Un bărbat în vârstă de 55 de ani s-a prezentat la camera de gardă acuzând dureri la nivelul hemiscrotului stâng şi tumefacția acestuia, în evoluție de 2 săptămâni. Pacientul neagă prezența vreunui eveniment traumatic la acest nivel. La examenul clinic local se decelează o formațiune dură de aproximativ 15-20 de $\mathrm{cm}$ de la nivelul posterior al scrotului până la orificiul inghinal superficial. Examenul clinic nu indică alte modificări la nivelul organelor genitale externe şi nu poate exclude o eventuală hernie încarcerată. Examenul ecografic Doppler a confirmat suspiciunea de tromboză de venă testiculară cu întreruperea totală a fluxului sanguin. În urma efectuării unui examen CT de urgență s-a stabilit că trombul se întinde până la nivelul orificiului inghinal extern. A fost preferat abordul chirurgical pentru a exclude eventualitatea unei hernii încarcerate şi s-a practicat excizia venei trombozate, fără complicatiii. Conduita postoperatorie a constat în administrare de apixaban pentru 30 de zile, medicație stabilită la indicația consultului cardiologic.

Concluzii: Evaluarea ecografică Doppler reprezintă standardul de aur pentru diagnosticarea trombozei de venă spermatică. Managementul terapeutic este un subiect controversat între abordul chirurgical sau tratamentul conservator. 
Cuvinte cheie: tromboză venă spermatică, varicocel, durere testiculară, ecografie scrotală

\begin{abstract}
Introduction:Spermatic vein thrombosis is a rare entity with poor clinical distinctive signs for the differential diagnosis, which raises numerous controversies about the appropriate management.

Case report: A 55 years old man presents at the emergency room for left scrotal pain and swelling evolving for two weeks. The patient denied any recent local traumatic event. Physical examination revealed an approximately 15 to $20 \mathrm{~cm}$ length mass from the posterior scrotum to the external inguinal orifice. The other genitals had a healthy appearance at the moment of the examination. An incarcerated hernia couldn't be excluded. The Doppler ultrasound evaluation of the scrotum confirmed the suspicion of left testicular vein thrombosis with complete cessation of blood flow. Both testicles appeared to have regular blood flow. CT scan established that the thrombus extended up to the left external inguinal orifice. Surgical treatment was preferred to address an eventually incarcerated hernia. The left testicular vein was excised from the external orifice. Postoperative management consisted of apixaban for 30 days, and the cardiology department thus conducted the treatment.

Conclusion: Doppler ultrasound evaluation of the scrotum represents the gold standard diagnostic test for spermatic vein thrombosis. There are still controversies about the management approach of this pathology, conservative or surgical.
\end{abstract}

Key words: spermatic vein thrombosis, varicocele, testicular pain, scrotal ultrasound

\section{Introduction}

Venous thrombosis is caused by blood clots forming in the vessels and usually affects the superficial and deep veins of the lower limbs. However, it is known that the thrombotic process can affect every venous district (1). A relatively rare group of venous thrombosis is represented by those related to cerebral sinuses, upper limbs or splanchnic system. A less frequent group that is usually underdiagnosed is represented by thromboses affecting the jugular vein, right heart, iliac vein, renal, ovarian, and testicular veins or dorsal penile vein. Some studies consider that this pathology condition has an estimated incidence of $70-180 / 100,000$ people in the United States (2).

Spermatic vein thrombosis is an unexpected and rare finding in patients with acute scrotal pain, which requires careful management. There is limited data with less than 25 cases reported in the literature. Most cases were reported on the left side, but there are also simultaneous bilateral reports. There are no guideline specifications to attest spermatic vein thrombosis as a distinct entity, and apparently, it is related to recurrent venous thrombo-embolism. The differential diagnosis excludes other pathologies such as epididymitis, incarcerated inguinal hernia, torsion of the spermatic cord, and spermatic cord tumors (3). Commonly, thrombosis affects the left spermatic vein, and the presenting symptoms include located pain and swelling, which are gradually worsening. Clinically is a challenging situation that requires prompt evaluation using a Doppler Ultrasound scan of the scrotum for an accurate diagnosis. Although conservative management is described, the standard management remains the surgical approach to exclude and address the eventually incarcerated hernia. 


\section{Case Report}

A 55-year-old man presented to our department at the emergency room for left scrotal induration and increasingly associated pain, gradually evolving for two weeks. The patient denied any significant urological past. Before the hospital admission, written informed consent of the patient was obtained. The patient denied any recent trauma, surgical history or chronic disease. A recently general exam revealed high values of the arterial pressure about $165 / 80 \mathrm{mmHg}$. From the physical evaluation, we noted a height of 185 $\mathrm{cm}$ and $96 \mathrm{~kg}$ weight with a calculated body mass index of 28 .

The local examination revealed normal configured external genitals, without traumatic marks, with an approximately 15 to $20 \mathrm{~cm}$ length mass from the posterior scrotum to the external inguinal orifice. The mass was not adherent to the surrounding tissues and presented increased pain with palpation. An incarcerated hernia could not be excluded. Enlarged prostate with typical configuration was noticed at the digital rectal examination. The patient also underwent a general surgery evaluation and, afterward, was hospitalized. Blood test results were within the normal range (4). Urine tests revealed no evidence of macroscopic or microscopic hematuria or any signs of infection.

A Doppler scrotal ultrasound evaluation (Fig. 1, 2) confirmed the diagnosis of left spermatic vein thrombosis with complete cessation of blood flow. For a more accurate diagnosis, it was essential to perform an abdominopelvic CT scan evaluation (Fig. 3) rather than an abdominal ultrasound. It showed a left spermatic vein thrombosis extended from the posterior scrotum to the external inguinal orifice. No renal tumors or vein compressions were revealed.

The surgical management was decided to exclude and address an incarcerated hernia. A transversal incision of the left scrotum was performed. Intraoperative evaluation after dissection revealed a thrombosed testicular vein, with an approximately $20 \mathrm{~cm}$ length

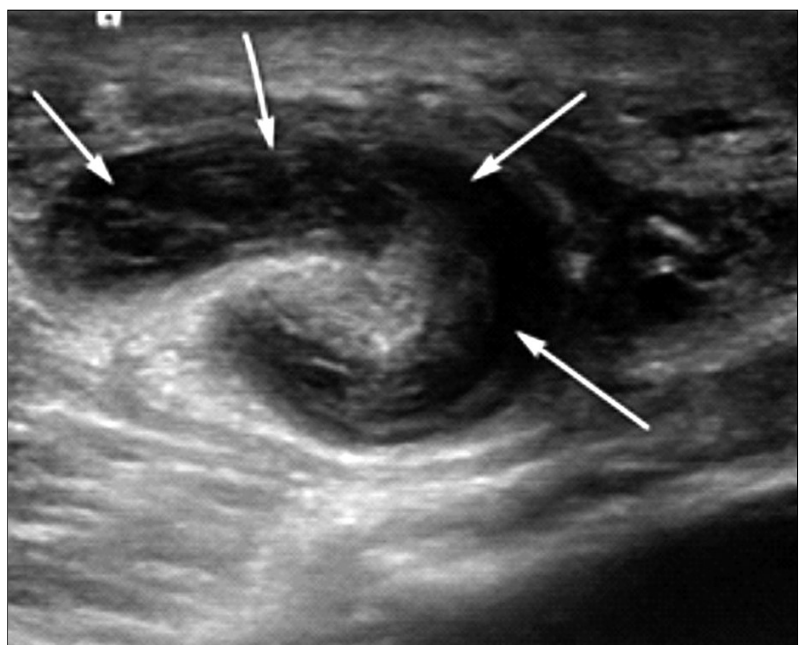

Figure 1. Ultrasound showing echogenic intraluminal thrombus (arrows) in the dilated left testicular vein with thickened walls

(Fig. A), and the typical configuration at the superficial inguinal orifice, so the abnormal vein was excised after ligation. A small hernia was revealed, and the left testicle had a healthy aspect. The patient was hospitalized for five days with no out of the ordinary postoperative course and discharged with recommendations for cardiological follow up. Oral therapy with apixaban was established

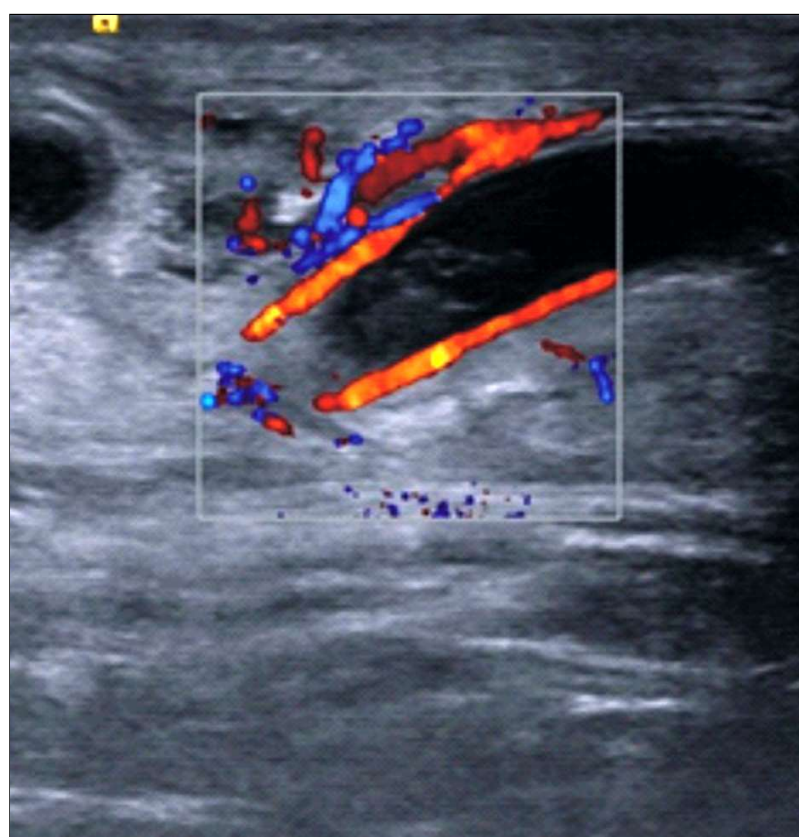

Figure 2. Colour Doppler ultrasound showing no filling with the color in the lumen of spermatic vein 


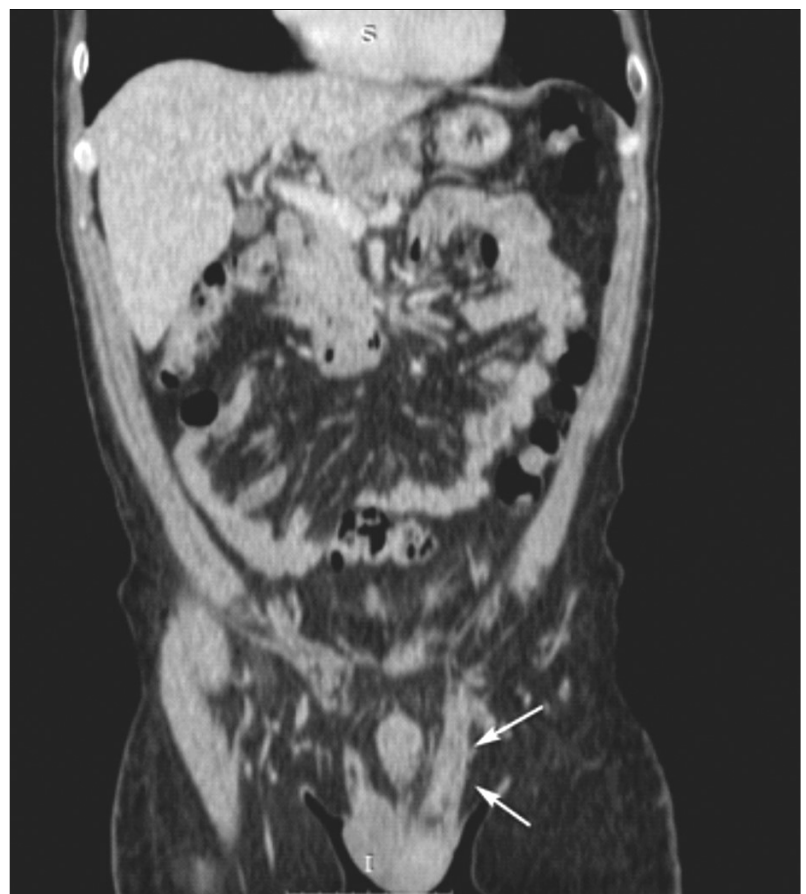

Figure 3.
CT - coronal view - left spermatic vein thrombosis (arrows)

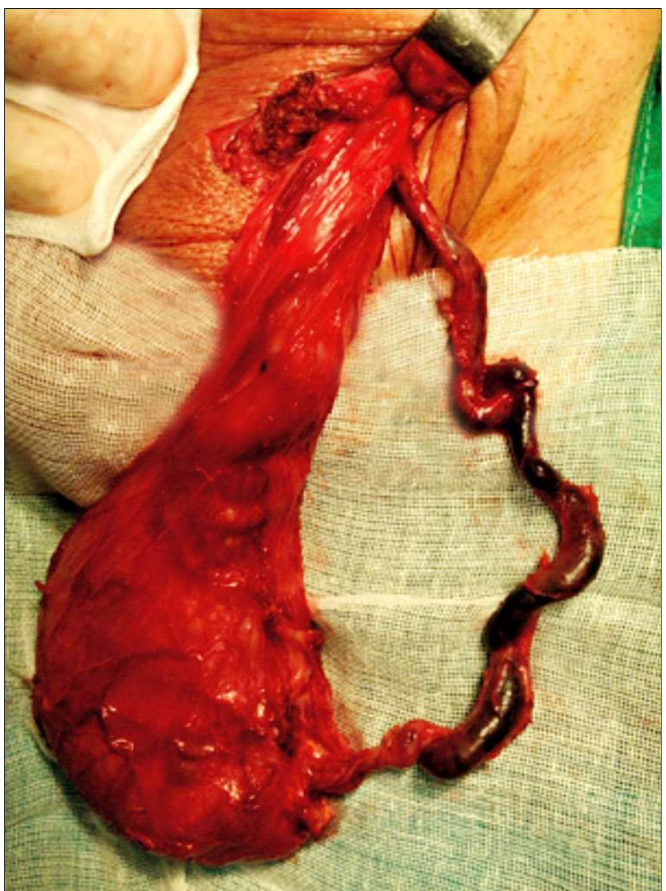

Figure 4. Intraoperative photograph of the left testis delivered through an ipsilateral transverse hemiscrotal incision. A large thrombus is visible in the spermatic vein for 30 days under cardiological supervision. The local inflammation was reduced two weeks after the intervention. Informed written consent was obtained to publish his case (including publication of images).

\section{Discussion}

Testicular vein thrombosis is an uncommon pathology confronting us with a difficult differential diagnosis, being easily misdiagnosed and confused with other pathologies because of the lack of specific clinical aspects. There is still no clear consensus about the treatment management, conservative or surgical, with few cases published in the literature. The presentation symptoms like pain and swelling, usually located on the left side, are nonspecific (5). Classically, three factors are involved based on Virchow's triad: stasis, coagulation, and mural factors. The origins of this condition remain unclear. Many authors relate it to pathological changes like varicocele, obstruction on the venous drainage (renal tumors, trauma, heavy exercises, or prolonged sexual activity), coagulopathies, or other systemic diseases (6). The anatomical characteristics that involve left renal vein compression by a superior mesenteric artery, known as the nutcracker syndrome (7) and poor representation of valves at the left spermatic vein level, might explain left side varicocele. The anatomical peculiarities of the left side associate an increased risk for varicocele. We mention here the perpendicular angle between the spermatic vein and the left renal one and the increased pressure caused by the position of the left renal vein when joins vena cava (almost $10 \mathrm{~cm}$ above the right renal vein).

Because of secondary infertility with a significant loss of testicular function, varicocele is usually diagnosed at an early age, with a prevalence of approximately $15 \%$ in the male population. Even though nowadays the gold standard in treatment management is the microscopical surgical approach; more and more studies are revealing significant results 
for percutaneous embolization of the spermatic vein as a minimally invasive technique with great benefits and reduced complication rate.

One study conducted by Lenz et al, who analyzed a series of cases of testicular vein thrombosis (TVT) from Mayo Clinic, revealed a high association with previous malignant pathologies in the abdominal cavity. It suggests that once spermatic vein thrombosis was diagnosed, the patient should be carefully assessed for underlying malignancy conditions (8). Spermatic vein thrombosis can also be associated with deficiencies of protein $\mathrm{C}$ or $\mathrm{S}$, as some studies revealed for recurrent episodes $(9,10)$. In his research, Bolat et al. showed that heterozygosity for Factor V Leiden mutation could be a risk factor for this pathology (11). Murthy et al. described a case of a TVT associated with ulcerative colitis. They observed the high impact of sepsis or autoimmune diseases, their prothrombotic activities that determine thrombosis (12).

After McGavin, who reported in 1935, the first case of spermatic vein thrombosis (13); no more than 25 cases were registered in recent studies. The unspecific clinical manifestations require imagistic acquirements for a precise diagnostic. Ultrasonographic evaluation is considered to be the gold standard procedure test to evaluate the scrotal content and also the eventual thrombus. For more accurate details, it can be completed with a CT scan, which can reveal the thrombus extension in relation to the external inguinal ring and which can also establish the etiology of the disease (14).

There is no standardized optimal treatment for this rare pathology. Some investigators consider that medical treatment with anticoagulant and symptomatic drugs combined with a lack of effort and testicular support should be the first intention treatment. Some recent studies revealed that anticoagulating medications should be taken when the risk venous thrombosis recurrence is higher than $5 \%$ at 1 year or $15 \%$ at 5 years $(15,16)$.

The majority of surgeons agree on the fact that surgical exploration with or without thrombus removal is more appropriate to exclude other pathologies such as spermatic cord torsion, tumors, or incarcerated hernia (12). Testicular infarction secondary to spermatic vein thrombosis was reported in only one case (17).

\section{Conclusion}

Testicular vein thrombosis is an uncommon condition that can be diagnosed in a patient with no apparent risk factors making it a pathology to be taken into consideration when presenting for unspecific symptoms. Clinically, pain and swelling are the most frequent symptoms. Ultrasound evaluation has both high sensitivity and specificity, and it is considered the gold standard imagistic test. The CT scan, in our case, proved to be an essential diagnostic tool.

Surgical exploration remains necessary to exclude complicated inguinal hernia suspicion. Knowing the fact that this pathology can represent an early sign of neoplasia, further follow up guidelines for these patients are necessary.

\section{Conflict of Interest}

The authors declare no conflict of interest.

\section{References}

1. Tica OA, Tica O, Antal L, Hatos A, Popescu MI, Stoian AP, et al. Modern oral anticoagulant treatment in patients with atrial fibrillation and heart failure: insights from the clinical practice. Farmacia. 2018;66(6): 972-6.

2. Heit, JA. The epidemiology of venous thromboembolism in the community. Arterioscler Thromb Vasc Biol. 2008;28(3):370-2.

3. Kleinclauss F, Della Negra E, Martin M, Bernardini S, Bittard H. Thrombose spontanée d'une varicocèle gauche. Prog Urol. 2001; 11(1): 95-6.

4. Petca A, Radu DC, Petca RC, Mehedintu C, Barac RI, Ionescu A, et al. Current trends of liquid chromatography tandem mass spectroscopy use in clinical gynecology. Rev Chim. 2019;70(6): 2021-5.

5. Castillo OA, Diaz M, Vitagliano GJ, Metrebian, E. Pulmonary thrombembolism secondary to left spermatic vein thrombosis. Urol Int. 2008;80(2):217-8.

6. Gleeson MJ, McDermott M, McDonald G, McDermott TE. Spontaneous thrombosis of the left spermatic vein. $\mathrm{Br} \mathrm{J} U$ rol. 1992;70(5):567.

7. Kurklinsky AK, Rooke TW. Nutcracker phenomenon and nutcracker syndrome. Mayo Clin Proc. 2010;85(6):552-9.

8. Lenz CJ, McBane RD, Cohoon KP, Janczak DT, Simmons BS, Saadiq RA, et al. Testicular vein thrombosis: Incidence of recurrent venous thrombembolism and survival. Eur J Haematol. 2017; 
100(1):83-7.

9. Griffin JH, Evatt B, Zimmerman TS, Kleiss AJ, Wideman C Deficiency of protein $C$ in congenital thrombotic disease. J Clin Invest. 1981;68(5):1370-3.

10. Comp PC, Emon CT. Recurrent venous thrombembolism in patients with a partial deficiency of protein $\mathrm{S}$. $\mathrm{N}$ Engl $\mathrm{J}$ Med. 1984;311(24):1525-8.

11. Bolat D, Gunlusoy B, Yarimoglu S, Ozsinan F, Solmaz S, Imamoglu $\mathrm{FG}$. Isolated thrombosis of right spermatic vein with underlying Factor V Leiden mutation. Can Urol Assoc J, 2016;10(9-10):324-7.

12. Murthy PB, Gill BC, Khurana S, Nyame YA, Sabanegh ES, Kaouk JH. Spermatic Vein Thrombosis. Urology. 2018;119:32-4.

13. McGavin, D. Thrombosis of the pampiniform plexus. Lancet. 1935;226:368-9.

14. Amador Robayna A, Rodríguez Talavera J, Ballesta Martínez B,
Falcón Barroso J, Carrión Valencia A, Orribo Morales N, et al. Deep Vein Thrombosis: A Rare Cause of Acute Testicular Pain. Case Report: Literature Review. Urol Int. 2018;101(1):117-20.

15. Kearon C, Iorio A, Palareti G; Subcommittee on Control of Anticoagulation of the SSC of the ISTH. Risck of reccurent venous thrombembolism after stopping treatment in cohort studies: recommendation for acceptable rates and standardized reporting. J Thromb Haemost. 2010;8(10):2313-5.

16. Kearon C, Spencer FA, O'Keeffe D, Parpia S, Schulman S, Baglin T, et al. D-dimer testing to select patients with a first unprovoked venous thrombembolism who can stop anticoagulant therapy: a cohort study. Ann Intern Med. 2015;162(1):27-34.

17. Coolsaet BL. The varicocele syndrome: venography determining the optimal level for surgical management. J Urol. 1980;124(6): 833-9. 